ROCZNIKI TEOLOGICZNE

Tom LXVIII, zeszyt $7-2021$

DOI: https://doi.org/10.18290/rt21687-7

IOAN GEORGE KRAUCIUC

\title{
HISTORY AND TRADITIONS \\ OF THE ORTHODOX UKRAINIAN COMMUNITY IN MARAMURES
}

\begin{abstract}
Maramureș County, located in the north-western part of Romania, has always represented one of the oldest religious centres of the ancient province of Transylvania. The first part of the present essay will illustrate the most relevant moments in the history of the Christian community of Orthodox Ukrainian people, who lived within the historical region of Maramureș, and also the structure and the evolution of the local Ukrainian Church. The second part will present and demonstrate the key role played by the Orthodox faith and beliefs in establishing mutual relations of friendship and collaboration between the smaller Ukrainian community and the larger Romanian population, within the boundaries of Maramureș County. These relations of friendship and mutual understanding must endure in order to fight against the newly emerging Antichristian ideology that has shaken the moral and Christian foundations of our society. By sharing the same faith and the same religious beliefs, members of the Ukrainian community have managed to preserve their customs and traditions, their traditional dress codes, music and dance and kept alive their spiritual heritage.
\end{abstract}

Keywords: Maramureș; Orthodoxy; Ukrainians; tradition; identity.

\section{INTRODUCTION}

Maramureș County, as it has often been referred to in the Romanian historical tradition, is a region that covers an area of approximately 10,000 square kilometres, located in the north-western part of the Carpathian Mountains, and divided by the waters of the Tisa River. Nowadays, the northern section of this ancient region is part of Ukraine, while the southern section

IOAN GeORge Krauciuc, PhD student, Faculty of Orthodox Theology "Episcop Dr. Vasile Coman," University of Oradea, 1 Universității Street, Oradea, 410087, Bihor, Romania; e-mail: ioan_krauciuc@yahoo.com 
lies within the borders of Romania. Maramureș County is first mentioned in AD 1199 in a document issued by the Hungarian king, Emeric the First. In the document, the king offers a large plot of land to one of his most trusted counts, Laurențiu, who had saved the king's life during a hunting expedition. ${ }^{1}$ But the history of Maramures goes back a lot further, its origins being lost in the mists of time. The Romanian people inherited those lands from the ancient Dacian people and the region kept its boundaries intact until the end of World War I, when only a small part of it was lost to Bereg-Ugocsa County during the reign of Matthias Corvinus. ${ }^{2}$

The population living here displays a remarkable ethnic diversity. Alongside the Romanian community, there are also significant Ukrainian, Hungarian and German communities, with their own religious beliefs and traditional customs. The presence of the Ukrainian community is closely related to the history of the Ruthenian people, whose history is still shrouded in mystery even to this day.

The name Ruthenia is first mentioned during the Middle Ages. In the old texts, several linguistic terms are used to describe this people (Ukrainian Ruthenians, Carpathian Ruthenians, Transcarpathian Ruthenians) but the description is usually approximate, failing to provide specific evidence or details. All that is really known about them, according to different sources from the Middle Ages, is that they occupied a territory located near the western slopes of the Carpathians: from Maramureș to Ung. Large communities of Ruthenians were also found in the Carpathian part of Russia and in different parts of the Kingdom of Hungary. Those communities were rather dispersed, and quite independent, rather than forming a single, centralized state. ${ }^{3}$

\section{A SHORT HISTORY OF MARAMUREȘ COUNTY}

Human presence throughout the vast territory of the historical Maramures region is first documented by Roman scholars, following the Roman conquest

\footnotetext{
${ }^{1}$ Documents concerning the history of Romania, C series, column I, document 29, pages 16-17, in Stefan Vișovan, Interferenţe româno-ucrainene în toponimia Maramureşului [Romanian-Ukrainian interferences regarding the Maramureş' toponymy] (Baia Mare: Umbria, 2001), 11.

${ }^{2}$ Nuțu Roșca, Istoria Bisericii Ortodoxe Române din Maramureş [A history of the Romanian Orthodox Church of Maramures] (Baia Mare: Romanian Orthodox Episcopate of Maramures, Sătmarului, 2015), 74.

${ }^{3}$ Sergiu Columbeanu, Cnezate şi voievo-date româneşti [Romanian Principalities and Voivodeships] (Bucharest: Albatros, 1973), 53.
} 
of the ancient kingdom of Dacia. The northern territories that bordered the Roman province of Dacia (AD 107-271) were inhabited by the tribes of the free Dacian people, and later, following the Slavic Migrations, by tribes of Slavs. The borders between the Roman Dacia and the free northern territories seem to have been no impediment. ${ }^{4}$ Several Roman coins were discovered in different parts of those northern territories, providing evidence that there were frequent commercial exchanges between the people from the Roman province and the free people living outside the borders of the Empire. Archaeologists have also discovered a votive tablet pertaining to a certain Januarius, a money changer from the second century AD. According to the Romanian scholar Ioan Mihaly de Apșa, this votive tablet, found in the vicinity of the Rona de Jos and Crăciunești villages, was the first Roman inscription to be discovered in Maramureș County. ${ }^{5}$ Another relevant piece of evidence found here was a stone tablet measuring 1.80 meters in height, with the following letters engraved: V.B.H.S.V. Although unidentified, this tablet also shows early Roman presence.

During the fourth century AD, Europe witnesses barbarian invasions, when several peoples - most notably the Goths, the Huns, the Gepids, the Pannonian Avars and the Slavs - invade the former Roman territories. The Slavs arrive in the eastern part of Europe somewhere around the end of the sixth century. We shall focus on the White Croats, a Slavic tribe that lived and thrived in the north-eastern and south-western parts of the Carpathian Mountains at around ninth century. ${ }^{6}$

Later on, during the tenth century, most of Transcarpathia became part of the Galicia-Volhynia principality until, in the first part of the thirteenth century, the Tatars invaded these lands (in AD 1240). ${ }^{7}$ Between 1264 and 1300, Leo I of Galicia, the son of Prince Daniel of Galicia, invaded and conquered most of the region which, by then, was occupied by the Hungarians. Following his conquest, many Ukrainian families came to settle there, either establishing new settlements or joining the already existing Slavic communities. Under the rule of Leo I, the lands continued to be part of the Principality of Galicia-

\footnotetext{
${ }^{4}$ Kacsó Carol, Repertoriul arheologic al judeţului Maramureş [The archaeological repository of Maramureș County] (Baia Mare: Eurotip, 1992), 240.

${ }^{5}$ Ioan Mihaly de Apșa, Diplome maramureșene din sec. XIV-XV. Istoria Comitatului Maramureș [Maramureș nobiliary diplomas from the 14th and 15th centuries. The history of Maramures County] (Maramures-Sziget: Mayer and Berger,1900), 65.

${ }^{6}$ Vladislav Hubarev, Istorija Ukrainy [A history of Ukraine] (Donetsk: Strim Press, 2007), 12.

${ }^{7}$ Nicolae Pavliuc, "Do istoriji ukrajinskich sil Maramoroščyny [Excerpts from the history of the Ukrainian villages of Maramures]," Vilne slovo 16-17 (1990): 8.
} 
Volhynia until 1327, when, after a series of armed conflicts, the armies of the Kingdom of Hungary managed to reconquer them. ${ }^{8}$ It is possible that, during those times, many Hutsuls ${ }^{9}$ arrived and established themselves in Maramureș.

\section{THE PRESENCE AND EVOLUTION OF UKRAINIAN COMMUNITIES IN MARAMUREȘ}

Ukrainian communities have been present in Maramureș since ancient times. They lived in peace and prosperity, thriving among the much larger Romanian communities. However, the existence of several Ukrainian settlements is mentioned only later, approximately two centuries after the acknowledgement of Maramureș County as a historical and political entity. ${ }^{10}$

The largest community of Ruthenian people arrived in Maramureș during the fourteenth century (approximately 1360), under the rule of Prince George Koriatovich. A part of this large community continued to advance, going deeper into the heart of the Maramures region, where they came under the rule of Johanis Woyvode, and were invited to found new settlements along the Ruscova River. Thus came into existence the old villages of Ruscova (1373), ${ }^{11}$ Sieu (1373), Rozavlea (1373) and a few years later Repedea (1413) and Poienile de sub Munte (1411). ${ }^{12}$

According to Alexandru Filipaşcu, during the fifteenth century the local nobility brought numerous Ukrainian families to help them work their lands. This fact is clearly pointed out by documents issued sometime during the seventeenth and the eighteenth centuries, containing lists of servants' names, the majority of whom were of Ukrainian origin. ${ }^{13}$

\footnotetext{
${ }^{8}$ Nicolae Pavliuc, Istorija Ukrajiny [History of Ukraine] (Kiev: Orizonturi, 1989): 40.

${ }^{9}$ The Hutsuls are an ethnic subgroup of Ukranians, without being considered as forming a wellestablished nation. The Hutsuls came to Maramures around the same period of time as the Boykos. (Cf. Hodinka Antal, A munkácsi görög-katholikus püspökség története [A history of the Greek Catholic Eparchy of Mukačevo] (Budapest: Kiadja a magyar tudományos akadémia, 1909), 73.

${ }^{10}$ Ștefan Vișovan, Interferenţe româno-ucrainene în toponimia Maramureşului [RomanianUkrainian interferences regarding the Maramures toponymy] (Baia Mare: Umbria, 2011), 9-12.

${ }^{11}$ The year when the settlement was first mentioned is written in between brackets, according to Coriolan Suciu, Dictionar istoric al localităților din Transilvania [Historical dictionary of human settlements in Transylvania], vols. 1-2 (Bucharest: Editura Academiei Republicii Socialiste România, 1967-1968), 56.

${ }^{12}$ Alexandru Filipaşcu, Istoria Maramureşului [History of Maramures], 2nd ed. (Baia Mare: Gutinul, 1997), 80; Radu Popa, Ţara Maramureșului în veacul al XIV-lea [Maramures County in the 14th century] (Bucharest: Editura Academiei Republicii Socialiste România, 1970), 56.

${ }^{13}$ Filipaşcu, Istoria Maramureşului, 80-81.
} 
Throughout the eighteenth century, there were a series of natural calamities that affected the life of the Ukrainian communities in Maramureș. Official documents from that period speak of plague epidemics, sometimes followed by cholera outbreaks, in 1700, 1708, 1711 and 1792, but also during the nineteenth century, between 1830 and 1838 . There were also years of famine in 1737, 1740, 1786 and 1815. Those years of famine were the result of a prolonged period of drought, followed by a decrease in temperature which irremediably compromised the crops. The Tisa River also caused havoc several times. The floods of 1738, 1742, 1747, 1775 and 1782 would claim numerous human and material losses and cause a lot of suffering for the survivors. ${ }^{14}$

In the early twentieth century, there was a certain spiritual renewal among the communities of the Ukrainian people living in Maramureș. New churches and parish houses were built, and new schools enabled access to education for all the young people. Many of them were born locally and managed to continue their studies: either at the local educational institutions or at the universities in the major cities of the Austro-Hungarian Empire. There was, however, a major setback between 1902 and 1907, when the new educational laws imposed by Albert Apponyi would lead to the introduction of the Hungarian language in all church schools. ${ }^{15}$

Also, during the twentieth century, the historical Maramureș County was divided into two sectors, the dividing line following the course of the Tisa River. The reason for this division was mainly an ethnical one, implemented according to the Wilsonian principle of self-determination of people. In the territories north of the Tisa the vast majority consists of Ukrainian people, while the southern part is inhabited by a Romanian majority. ${ }^{16}$

\footnotetext{
${ }^{14}$ Teofil Ivanciuc, Sighetul Marmației: ghid cultural-turistic [Sighetul-Marmației - Cultural and Tourist Travel Guide] (Sighetul Marmației: Echim, 2007), 80.

${ }^{15}$ Andrei Olașin, Istorija Zakarpatia [The history of Trancarpathia] (Mukacevo: Karpatska vezha, 2009), 78.

${ }^{16}$ Nicolae Boar, Regiunea transfrontalieră româno-ucraineană a Maramureștului [The Romanian and Ukrainian cross-border region of Maramures] (Cluj Napoca: Cluj University Press, 2005), 172.
} 


\section{THE UKRAINIAN COMMUNITY OF MARAMURES \\ AND ITS INSTITUTIONAL CHURCH: THE UKRAINIAN ORTHODOX VICARIATE - AN UNUSUAL PRESENCE WITHIN ROMANIAN ORTHODOXY}

Throughout all Romania, the Romanian Orthodox Church is organised in metropolitanates, archdioceses, episcopates and parishes. There are also Orthodox communities located abroad, which offer counsel and support to those Romanian families who live and work abroad. The presence of an autonomous Ukrainian Orthodox Vicariate, located here in Maramureș, demonstrates the ecumenical spirit of the Romanian Orthodox Church, as it welcomes its Ukrainian Orthodox brothers and sisters. There is a special bond between the Ukrainian and Romanian communities: they have learned to live together in peace and harmony, sharing their Orthodox faith and strengthening their belief in God and Church, while preserving their customs and traditions.

This collaboration between the Romanian Orthodox Church and the Ukrainian Orthodox Vicariate has an interesting long history, which deserves to be mentioned here.

At the beginning of the eighteenth century, the Ukrainian Orthodox parishes were under the authority of the Ruthenian Greek Church of Mukachevo (the village of Grusevo, Russia), and later came under the sovereignty of the Hungarian (Greek) Catholic Archeparchy of Hajdudorog.

After the end of World War I, there were a series of major economic, social and political changes throughout the whole region. These changes also influenced the cultural and religious climate. Maramureș County became incorporated into the newly born state of Greater Romania (1918). Unfortunately, a large part of the historical Maramures region, south of the Tisa, was lost to Czechoslovakia. Thus the Ukrainian parishes, located on the Romanian side, ceased to be under the authority of the Hungarian (Greek) Catholic Archeparchy of Hajdudorog. The following years witnessed the birth of the new Ukrainian Orthodox Vicariate, with its headquarters in the city of Sighetu Marmației. ${ }^{17}$ And the story continues.

In 1930, the Ruthenian (Ukrainian) Vicariate was established in Cernauți (Bukovina), under the guidance of Father Simonici Mihai. His appointment as Vicar General lasted until 1940, when the Soviet Union addressed an ultimatum to Romania, demanding the territories of Northern Bukovina and Bessarabia.

\footnotetext{
${ }^{17}$ Vasile Penzeș, Історія Українсъкої греко-католицъкої церкви в Марамурені та всієі Румунії [The history of the Ukrainian Greek Catholic Church in Maramureș] (Lviv: Limes-Lecton, 1994), 34
} 
Forced by the political situation, Romania was compelled to agree to the terms, and the territories became part of the Soviet Union. Another surprising aspect worth mentioning here is that all the correspondence between the Ruthenian (Ukrainian) Vicariate and the Ukrainian parishes from Maramureș was written in Ukrainian. ${ }^{18}$

After 1940, the Vicariate of the Ukrainian Greek Catholic Church was relocated to Maramureș, headquartered at Sighetu Marmației. Father Andrei Sabostav was appointed Vicar General, followed by Protopope Andrei Medvețchi, who led until $1948^{19}$ when the Vicariate was dissolved. The following year, in 1949, the Vicariate was re-established under the name of The Ukrainian Orthodox Vicariate of all the Ukrainians from the Popular Republic of Romania. This newly established vicariate was under the authority of the Romanian Orthodox Church, with Father Vasile Penzeș temporarily appointed as Vicar General, until 1952. The same year, the vicariate was once again dissolved and was replaced by the newly created Archpriestship of the Ukrainian Orthodox Church in Romania. The Archpriestship of the Ukrainian Orthodox Church was headquartered at Poienile de sub Munte (commune in Maramureș) under the guidance of Father Vasile Boico. Father Vasile Boico continued as the Vicar General for 25 years, until 1977, when he was replaced by father Ioan Pițura from Ruscova. As a consequence, the Archpriestship of the Ukrainian Orthodox Church was relocated from Poienile de sub Munte to Ruscova.

During the communist Regime, around 1963, all the schools teaching the Ukrainian language were closed and the churches became the only places where the use of the Ukrainian language was still allowed. ${ }^{20}$

After the fall of the communist Regime, in December 1989, there were a series of major social and political changes that influenced the religious life of both Romanian and Ukrainian communities. As for the Ukrainian communities, during a meeting that took place on February 12, 1990, the Holy Synod of the Romanian Orthodox Church decided to "re-establish the Ukrainian Orthodox Vicariate, with its official seat in Sighetu Marmației, under the jurisdiction of the Romanian Orthodox Church, as it had been before, between

\footnotetext{
${ }^{18}$ See the documents from the Archive of Poienile de sub Munte Parish, No. 1, "Maramures County," entries registered between 1912-1914 and 1930-1940.

19 Penzeș, Історія Українсъкої, 47.

20 "Problemele parohiilor din Vicariatul Ortodox Ucrainean în atenția Permanenței Consiliului Național Bisericesc [The different concerns of the parishes of the Ukrainian Orthodox Vicariate are brought to the attention of the National Council of Churches]," Basilica, September 3, 2009, accessed January 12, 2021, http://basilica.ro/ro/stiri.
} 
1948 and 1952, when it was dissolved, under the guidance of Father Ioan Pițura, appointed as vicar." 21

During the same meeting, Father Vasile Lauruc, the parish priest of the Ukrainian Orthodox Church of Sighetu Marmației, was elected as Secretary. In the following years, father Vasile Lauruc would become a counsellor of the Ukrainian Orthodox Vicariate.

The Ukrainian Orthodox Vicariate has jurisdiction over two archpriestships. The Sighetu Marmației Archpriestship is composed of fifteen parishes and two monasteries (a convent for nuns, and a monastery sheltering a monk community) and is under the guidance of Archpriest Ioan Pițura, who is also the vicar of the Ukrainian Orthodox Vicariate. There is also the Lugoj Archpriestship, with thirteen parishes and a convent of nuns, located in Timiș and Caraș-Severin counties, under the guidance of Archpriest Ilie Albiciuc. ${ }^{22}$

The Ukrainian parishes of Maramureș are found along the Tisa River, near the Ukrainian-Romanian border. ${ }^{23}$ It is worth mentioning that three of the fifteen parishes located in Maramureș County can be found in the village of Poienile de sub Munte. ${ }^{24}$

\section{THE ORTHODOX FAITH: THE INEXTRICABLE BOND OF COMMUNION BETWEEN THE UKRAINIAN AND ROMANIAN COMMUNITIES}

The history of the ancient Maramureș County belongs to both the Ukrainian and the Romanian people. For centuries, they lived together and shared their joys and sorrows. In hard times, especially during the communist era, their faith in God helped them and enabled them to live in peace and harmony. They discovered that they had so much in common, and although the com-

${ }^{21}$ Address no. 1432 (March 16, 1990) of the Patriarchate of Romania, accessed January 15, 2021, available in Romanian at http://patriarhia.ro/cancelaria-sfantului-sinod-197.html.

${ }^{22}$ The Statute of the Romanian Orthodox Church, adopted by the Holy Synod of the Romanian Orthodox Church on November 28, 2007, published in Romanian (Bucharest: Institutul Biblic și de Misiune al Bisericii Ortodoxe Române Press, 2007), 44.

${ }^{23}$ There is also a Ukrainian community in the Banat region, which was established at the beginning of the 20th century, when Ukrainian families came to work in the forest industry. They founded the villages of Zorile, Copăcele, Cornuțel, see Raularian Rusu, Organizarea spatiului geografic in Banat [Geographical distribution of communities within the Banat area] (Timişoara: Mirton, 2007), 274.

${ }^{24}$ Bela Songota, The Poienile de sub Munte Commune, Maramureș - Monography (Petrova: Țara Maramureșului, 2015), 198. 
munist regime tried to supress any religious expression, both Ukrainian and Romanian families continued to address their prayers to God, to go to church as often as possible, and to respect their customs and traditions. Despite the prohibitions imposed by the communist authorities, both Romanian and Ukrainian believers attended the religious feasts celebrated by the neighbouring parishes. They travelled together in large groups and were guided by the parish priests, carrying in their arms, the holy pictures of saints and the Church banners, while singing religious hymns.

After attending the Divine Liturgy, families joined together to celebrate, and those who had no relatives in the neighbouring community were invited by the locals into their homes, as guests. Faith in God united them, their different languages helped them enrich their spirituality, made them feel closer to each other, rediscovering together the values and teachings of the early Christian faith.

After the fall of the communist regime and the dissolution of the Soviet Union, Romania was among the first countries to recognize Ukraine as an independent state. The two countries began their collaboration by establishing diplomatic relations. ${ }^{25}$ On February 1, 1992, the new Romanian embassy in Kiev, Ukraine, was created in order to replace the previous consulate general, which had operating there since 1971. With the purpose of consolidating the economic and social bonds between the two people, the presidents of the two countries, Ukraine and Romania, began a series of official trips ${ }^{26}$ which resulted in the signing of a series of collaborative protocols. Also during these official meetings, there were a series of discussions regarding the social status of both Ukrainian and Romanian minorities. The first was held in Romania while the latter was in Ukraine. The social status of the Ukrainian minority in Romania is well established, being a well-organized community whose rights have been respected throughout the centuries. Unfortunately, that is not the case for the Romanian community in Ukraine. There are still a series of improvements that need to be made there to help the Romanian minority to preserve their national, cultural and religious identity.

\footnotetext{
${ }^{25}$ Ioan Marin Dermer, Maramureşul Românesc: studiu de geografie [The Romanian region of Maramureș: Geography studies] (Bucharest: Cartea Românească, 1933), 64.

${ }^{26}$ The Romanian president went on several official visits to Ukraine; in Kiev and Chernivtsi (1999, 2006), Kiev and Odessa (2002), Kiev (2005, 2015), Chernivtsi (2003). The Ukrainian president visited Romania: the cities of Constanța (1997), Bucharest (2005, 2006, 2008, 2016), and Sighetul Marmației (2007).
} 
The Romanian minority is the third most numerous population in Ukraine, after the Ukrainians and the Russians. The largest Romanian community is located around the Cernăuți region, with approximately 181,780 Romanian language speakers. The Transcarpathia region comes in second with approximately 32,152 people of Romanian origin, mostly distributed in Tiachiv (Teceu) and Rakhiv (Rahau) districts. There is also a large community of Moldavian people (around 123,751 people) that live in the area surrounding the port city of Odessa. Smaller communities of Romanian and Moldavian people are found in Kirovohrad, Nicolaev, Herson, Ananiev and Balta.

The Romanian community of Ukraine is confronted with several hindrances. There is a need for free access to education in their native language, particularly during the first years of study and preferably until the end of secondary education. Another issue is the necessity to adopt the Romanian language as an official language to be used in administration and justice. Other important issues to be addressed are: the insufficient financing of different associations that struggle to defend the rights of the Romanian communities, the necessity to implement different media programmes addressed to those communities, and the lack of elected representatives that would represent the interests of the Romanian minority at a national level. ${ }^{27}$

Despite all these obstacles, members of the Romanian community have managed to preserve their religious identity, to maintain their communion with God, and to live in harmony with their Ukrainian brothers and sisters.

There is an inextricable bond that unites the Ukrainian and Romanian communities, here in Maramureș. This bond lies within their common belief in God and His Son, Jesus Christ. Both Ukrainian and Romanian people share their love for the Orthodox faith and for the Church, their traditions and their families. They also strive to preserve their traditional folk costumes, and their traditional songs, in which they tell the legends and the history of their ancestral lands. In fact, the people of Maramureș County are well known all over the world for preserving and keeping their customs and traditions alive.

\footnotetext{
${ }^{27}$ Nicolae Pavliuc, "Completări la istoria satelor ucrainene din Maramureș [From the history of the Ukrainian villages of Maramureş]," in Noua Eră, 134-36 (Bucharest: Kriterion, 1957), 13.
} 


\section{AN OLD TRADITION OF MUTUAL RESPECT AND UNDERSTANDING BETWEEN THE ROMANIAN AND THE UKRAINIAN COMMUNITIES}

In the past centuries, both Ukrainian and Romanian communities were forced to defend and preserve their religious identity. They endured persecutions from those who, both politically and religiously, had governed and controlled a region which found itself trapped between the interests and ambitions of several powerful empires. Later on, during the communist regime, which had embraced atheism, all Christians faced even more treacherous and dangerous challenges in order to preserve their faith in God and the Church.

Secularization, the desecration of the natural world, and the increasing popularity of the Neo-Marxist ideology (guilty of transforming the ideal notion of liberty into an incontrollable permissiveness and corruption) irreparably affect the sacred communion of the bond between God and man, His ultimate creation. All Christians must seek their salvation by respecting their faith and the Church, and by addressing their prayers to God.

Nowadays, there is an ideological war going on - a war that tends to turn all the people into insecure and mindless creatures, devoid of their own will. People find themselves unable to discover their purpose, unable to turn towards God, and unable to seek their salvation amidst this sinful society. The culture we live in has lost its direction and its authentic values. It has turned its face away from God and considers man as the most powerful and important creature on Earth. It seems that people have forgotten that it was God who created mankind, and not the other way round. ${ }^{28}$ Therefore, we must praise and dedicate our lives to God and not to our own earthly passions and pleasures. In the past, the Church represented the most important institution of a community. Once again, people should find shelter within the Church in order to get closer to God and to redeem their souls.

Not only have the Ukrainian and Romanian communities undergone persecution, but the migration phenomenon itself can lead to feelings of separation and alienation. People who migrate from one country to another begin to feel estranged from themselves, from their families, and from God. Living in a different society, which has different rules and different priorities, can lead to anxiety, confusion and uncertainty.

\footnotetext{
${ }^{28}$ Ioan Bizău, Viata in Hristos si maladia secularizarii [The life in Christ and the disease of secularism] (Cluj Napoca: Patmos Press, 2002), 22; Hierotheos Vlachos, Secularismul. Un cal troian in Biserica [The Secularism, a Trojan horse within the Church] (Galați: Egumenița, 2004), 9.
} 
Migration can affect the social and economic balance of a community, too, and can lead to major cultural and religious changes. Furthermore, migration can influence the way of life of the community, destabilizing it and leading to the loss of moral and traditional values.

Probably the greatest effect of migration is upon the family. Being used to living together in harmony, the members of the Christian family resent the absence of the ones that have moved elsewhere. Those who are left behind must adapt to the new conditions and to a new way of life, but unfortunately that is not always possible. ${ }^{29}$

Both the Romanian Orthodox and Ukrainian Orthodox communities understand the danger represented by this unstoppable phenomenon of migration. They realize that, without God and the Church, the community will lose its moral and religious values, which will eventually lead to its dissolution: a dissolution that will eventually affect the whole world. ${ }^{30}$

Nevertheless, their instinct of self-preservation and their capacity to overcome all these hardships make these communities stronger. Their Orthodox faith and their belief in the ancient Christian teachings help them to face the challenges of this modern and secular society we inhabit.

Throughout history, whenever they found themselves in times of need, the Ukrainian community looked for help through faith, recognising that salvation lies within true belief in God. Today, together with their Romanian brothers and sisters, they gather in small communities called parishes. Here, they try to recreate the welcoming environment of the family, to reconstruct the homeland of their birth, and to preserve the memories deep within their souls, no matter where life may take them.

Whenever possible, especially during the most important religious celebrations such as the Nativity of Christ and Easter, those who are far away do their best to come home and reunite with their families. Celebrating together

\footnotetext{
${ }^{29}$ Tatiana Nagniebeda-Tverdohleb, Migrația - o dramă a timpurilor moderne. Școala secolului $X X I$, in condițile creșterii migrației tinerilor peste hotar [Migration - the drama of our contemporary times. 21st-century schooling versus the increasing phenomenon of migration of young people across borders] (Chişinău: Edmonton, 2013), 16.

${ }^{30}$ Petre Țuțea, Omul - Tratat de antropologie creştină [Man: A treatise of Christian anthropology], vol. 1, Problemele sau Cartea intrebărilor [Issues, or the Book of Questions] (Iași: Timpul Press, 1992), 22; Vasile Borca, Omenirea secularizată pe pantea suicidară [The secularized mankind heading towards moral suicide] (Baia Mare: Editura Universităţii de Nord, 2008), 27.
} 
in peace and harmony, while respecting the ancient Orthodox rituals and traditions, helps them rediscover their ethnic, religious and cultural roots.

Sharing the same Orthodox faith, the Ukrainian and Romanian people celebrate the same religious feasts. Whereas both communities celebrate Easter according to the ancient Julian calendar, the important feast of the Nativity of Christ is celebrated by each community at different times. The Romanian people celebrate Christmas, or the Nativity of Christ, on December 25 according to the newer Gregorian calendar, while the Ukrainian people celebrate it on January 7, respecting the tradition of the Julian calendar. This does not mean that the Holy Mass is different in any way, as the significance of the Nativity (or Christmas) stays the same for both communities. With joy and humility, they each celebrate the birth of the Holy Child, Jesus Christ.

There are, however, some differences because each community has its own traditional way to celebrate Christmas. All these specific rituals and customs are part of the spiritual heritage which defines the identity and personality of both ethnic groups.

\section{CUSTOMS AND TRADITIONS VIEWED AS AN EXPRESSION OF THE UKRAINIAN CHRISTIAN ETHOS}

Whereas, the age-old customs and traditions of both peoples are deeply rooted within the mist of ancient pre-Christian times, the earliest Christian influences originate from the Romanic and Slavic Christianisation of the region. The two civilizations, the Slavic settlements and the Roman Empire, shared common borders and cultural influences and have left their mark. However, it is still the case that a common feature of both cultures, Romanian and Ukrainian, is the way in which each remains partly influenced by the old pre-Christian superstitions.

These superstitions usually represent either the forces of nature, or some obscure beliefs that lie somewhere between witchcraft and pagan beliefs in the supernatural world of spirits. The communities embrace the Christian faith with all their hearts, by confessing their belief in God. They know that God has sacrificed his only son, Jesus Christ, to redeem mankind and to offer salvation to every Christian soul. However, some ancient pre-Christian traditions still endure, as people continue to worship certain forms and manifestations of spirits which they believe are capable of affecting the course of their lives: either in a favourable or a negative way. Even if all these rituals seem 
old and obsolete - the remnants of an ancient way of thinking - they are still present in the customs and traditions of the Ukrainian community, imbuing them with some sort of mystical aura: a mystical quality that characterized an ancient way of life, marked by the omnipresence presence of divinity.

The fact that the world of spirits is vividly present within the collective consciousness is demonstrated by the presence of a series of terms bearing a magical connotation. Although it is possible that younger generations may not be familiar with those terms, as the contemporary European context encourages a certain estrangement from the traditional and religious values, nevertheless, vocabulary denoting benevolent and malevolent entities does still co-exist. It represents a fundamental part of the Ukrainian communities' ethos, and is still used in the communities where traditional rituals are carefully preserved.

Whereas the benevolent spirits are less represented, the malevolent ones are a constant presence, leading us to believe that there is a constant fear of death within the collective consciousness, a fear of the maleficent forces of darkness that can invade the universe of the living, and affect the quality of life in general. Furthermore, we discover an impressive etymological variety of evil spirits, described by means of collective imagery, such as: ciort 'devil', vovkun 'werewolf', lisni 'forest fairies', zbisceata 'stillborn babies', vorojke 'witches', mara 'scourge', bosorkania 'undead'. There are, of course, a series of religious antidotes which can be used to fight these malignant spirits: healing plants, rosaries, incense, and the most efficient of them all, the sign of the Holy Cross. ${ }^{31}$

In the following pages, I will present how the Ukrainian community celebrate some of the most important Christian festivals. In addition to their religious significance, these feasts contain certain traditional elements of pagan origin, which lend their observances a unique character and which help to sustain the community's cultural identity.

The Nativity of Christ (Christmas) is celebrated on January 7. There is an old tradition practiced during Christmas Eve called carolling. Small groups of children gather together and go from house to house singing Christmas carols. If it is a small village, those groups visit almost every house in the community. The traditional Christmas carols are short songs, inspired by religious teachings which contain messianic texts. They are true confessions of faith, inspired by the religious event that marked the entire history of mankind: the birth of Jesus Christ in Bethlehem. The children are welcomed

\footnotetext{
${ }^{31}$ Vasile Gaftone, Românii şi etniile din Maramureş: o istorie a multietnicismului [Romanians and ethnic groups in Maramureș: A history of multiethnicism] (Baia Mare: Eurotip, 2010), 59.
} 
with great joy as they symbolically announce the birth of our Saviour. They receive gifts of apples, bagels, walnuts, or money. During Christmas Eve, the whole family has dinner together. For the symbolic dinner before Christmas Day, the Ukrainian Orthodox families prepare around twelve different dishes without meat. Here are some of the most popular dishes: boiled mushrooms mixed with oil and garlic, boiled corn with sugar and honey, roasted cabbage stew, dried plums and mushroom soup. All these delicious dishes are arranged on a big table, around three large traditional cakes (Vaselinache). ${ }^{32}$ Under the table, the family places a small cradle or a manger filled with straw. A chain is placed around the four table legs representing a symbolic shield meant to protect the newly born Jesus Christ against his enemies, King Herod and his soldiers. Another traditional ritual, specific to Christmas Eve, is an incantation meant to protect the cattle from diseases and wild animals. The family gathers around the table and performs it together: "Let the eyes and the legs of the wild beasts be bound together, as the legs of this table are, so that they can do no harm to none of our cattle." They sing the religious hymn dedicated to the birth of Jesus Christ (traditional carols) and the dinner ends with prayers of gratitude, as people thank God for all their blessings.

After midnight, people from the Ukrainian communities go to church and, under the guidance of the priest and the cantors, they sing Christmas carols and prepare to celebrate the first day of Christmas. ${ }^{33}$

\section{THE CELEBRATION OF THE DAY OF SAINT BASIL, OF THE CIRCUMCISION OF CHRIST AND OF THE NEW YEAR (JANUARY 13/14)}

All feasts mentioned above are also celebrated according to the old Julian calendar, which begins on present-day January 14 , and are marked by a series of deep-rooted and captivating traditions.

During the Old New Year's Eve, members of the Ukrainian Christian community go to church. There, at midnight, they celebrate a special mass dedicated to the coming of the New Year, traditionally called Novei Hut. At sunset, the children gather in small groups and go from house to house to

\footnotetext{
${ }^{32}$ Ioan M. Bota, Rona de Jos - prezentare monografică [Rona de Jos - a monographic presentation] (Sighetul Marmației: Viața Creștină, 2005), 89.

${ }^{33}$ Ivan Chlanta, Pisnja nad Karpatem [The song of the Carpathians] (Uzjhorod: Karpate, 1994), 87.
} 
announce the end of the old year and the coming of the new one (vinciuvanca). Families join together to celebrate with a festive dinner, where all kinds of traditional dishes are served. The following day, after attending the Church services, they continue celebrating at home.

After midnight, groups of the young unmarried men of the community, especially those bearing the name Basil (Vasile), visit the houses of the young eligible girls. After performing several traditional songs from their local area, they are invited inside the house to sit at the table and feast on all sorts of traditional dishes. This local tradition is called la legat and it is meant to bring young people together to facilitate future marriages within the community. Those girls who refuse to welcome the young men into their houses are symbolically punished. The young men remove the entrance gates form the girl's home and take them as far away as possible. This way, everybody within the community would eventually find out the identity of the girls who refused to welcome their guests. Certainly, this punitive action is perceived as a joke, and nobody feels offended by this part of the local tradition and folklore.

Palm Sunday (Metccova nedilea), also called the Triumphal Entry, is one of the Great Feasts of the Orthodox Church. It is celebrated on the last Sunday before Pascha or Easter. Respecting the religious traditions of the community, people go to church to attend a service. On this day, willow branches are blessed by the priests. After that, people go to the churchyard and light candles, while praying for the souls of the departed. They tap one another with these blessed willow branches, repeating the words: "Metica bie, ia ne biu, neni la tejdin velehidi" (The willow branch can hurt you, I won't do it, one week from now, the Pascha (Easter) will be here.) ${ }^{34}$

Pascha (Easter) or Feast of the Resurrection of the Lord. The Feast of the Resurrection of the Lord is the centre of the Orthodox Christian faith, and is celebrated accordingly by the Ukrainian communities. Before the beginning of Lent (a 40-day period of fasting and prayers), the women carefully wash all the tableware and cooking pots, preserving an age-old traditional ritual. All these dishes and pots would be used to prepare fasting meals during the seven week Lenten period that precedes Easter. A few days before Easter, each household is busy preparing the traditional dishes that will be served on Easter Day: traditional Ukrainian paska (the round, decorated, sweet Easter bread), homemade cakes, walnut and cheese rolls, and different meat-based dishes.

\footnotetext{
${ }^{34}$ Pavlo R. Magocsi, Formuvanya nationalinoyi samosvidomosti: Pidkarpatska Rus, 1848-1948 [Formation of national self-awareness: Subcarpathian Ruthenia, 1848-1848] (Ujgorod: Grinta, 1994), 296.
} 
Before attending the Easter Vigil, which starts at midnight, people go to the churchyard and light candles for the souls of the ones departed to the Kingdom of God. At dawn on Easter Day, each family fills a basket with traditionally painted eggs, paska and red wine and goes to church to celebrate the Resurrection of Christ. After the service, the baskets are left in front of the church to be blessed by the priests and each family has its own specific place, passed down from generation to generation (This means that traditions must always be preserved and never forgotten, because traditions keep alive the bond between the young generations and the ancestors.) After the baskets have been blessed, people go back to their homes, where they serve a festive Easter lunch and enjoy the traditional foods they prepared earlier. Before sitting at the table they knock Easter eggs, while greeting one another with the traditional Paschal Greeting "Christ is risen!" and responding "He is risen indeed!" Before eating, all the family says the Lord's Prayer and eat the traditional paska. Only then can the traditional feast begin. ${ }^{35}$

\section{REDISCOVERING THE TRADITIONAL FOLK COSTUME}

All the religious celebrations offer the current generation the chance to rediscover their traditional regional folk costumes, as nowadays, it is only in some remote villages hidden deep in the mountains, that some elderly people still wear these costumes on a daily basis.

However, during feast days and religious celebrations all the people of the Ukrainian communities, old and young together, proudly wear these traditional costumes to remind them of their traditional way of life and indigenous identity. In fact, this tradition of wearing folk costume and performing traditional folk songs and dances during religious feasts, define a community and preserve its ethnic, cultural and religious identity. The keeping of all these customs and rituals is meant to keep alive the cultural inheritance left by their ancestors, to strengthen the religious bonds between the members of the community and God, and to make the Ukrainian people aware of their unique identity among the other nations of the world.

\footnotetext{
${ }^{35}$ Ion Petrovai, Multiculturalism în Ţara Maramureşului: valori culturale ucrainene [Multiculturalism in Maramureș County - Ukrainian cultural values] (Cluj Napoca: Romanian Academy, Transylvanian Studies Centre, 2007), 73.
} 
There are some similarities between the Romanian and Ukrainian folk costumes but there are also several differences in terms of colours and sewing patterns. The main items that make up the Ukrainian folk costume are as follows.

The traditional linen shirt was sewn at home by the housewives and the young girls. The raw material, flax, was cultivated and processed by the family to obtain the linen thread. Then they used a traditional loom to produce fine linen fabric. From this fabric women sewed traditional shirts which could be simple or embroidered with different floral patterns. ${ }^{36}$ There were two different types of shirts, those worn by men and those made for women.

The traditional skirt was made of wool. The wool was carefully spun and then woven, using the same traditional weaving loom. The skirt was composed of two parts carefully sewn together with the help of a lace (poiaz in Ukrainian). We must also mention the traditional trousers, called ițari, made of cotton or wool, and leather sandals called opinci. Those sandals were carefully handmade from dried calf skin and were sometimes adorned with floral patterns. ${ }^{37}$

It is still customary for some women to wear beautifully woven headscarves. The younger women wear red headscarves, while the older women wear mostly black scarves. Nowadays, echoing the global rise in national nostalgia, there is a growing tendency for Ukrainians to imitate elements of their traditional dress. Most commonly adopted is the embroidered peasant blouse called $i a$. The modern versions of the blouse are made of silk but they still retain the various styles of floral patterns embroidered around the neck and on the sleeves. ${ }^{38}$

Similarly, from the Romanian folk costume, the traditional embroidered blouse called $i a$ is the most important item of clothing, with a history going back to the times of the Dacian ancestors of the Romanian people. ${ }^{39}$ It, too, has seen a rise in popularity in recent times.

\footnotetext{
${ }^{36}$ On May 19, the Ukrainians celebrate the day of the national embroidered shirt, called Vyshyvanka Day (Den Vişivanki).

${ }^{37}$ Ion Ștefănescu, Arta veche a Maramuresului [The old traditional art from Maramures] (Bucharest: Meridiane, 1968), 76.

${ }^{38}$ Ion Țelman, Ioana Mariş-Dăncuş, and Elisabeta Faiciuc, Cuhea în istoria şi cultura Maramureşului [Cuhea in the History and Culture of Maramureş] (Sighetul Marmației: Muzeul Maramureşului, 2005), 87.

39 "Povestea iei românești: cămașa populară, de la origini și până în present," Invie Traditia, accessed February 27, 2021, https://www.invietraditia.ro/editorial/ia-romaneasca.
} 


\section{CONCLUSIONS}

The history of the Ukrainian Orthodox communities of Maramureș is a defining part of the history of this region. Although their origin is still shrouded in mystery, they have been present here for centuries, and their contribution to the cultural and religious development of the society is undeniable. In spite of all the difficult times they have endured, due to the social, economic and political changes, they have succeeded in preserving their language, traditions, religion and cultural identity.

Their belief in God and the Church has helped them endure, and alongside their Romanian brothers and sisters, they continue to confess and embrace the Orthodox Faith. Their position is well established within the Romanian Orthodox Church, granting them religious freedom. They have developed and sustained a continuous cultural exchange with their Ukrainian "cousins" from across the border, while maintaining good relations with both the Romanian Orthodox community and the other confessional communities in the region.

In short, throughout the generations, the Ukrainian Orthodox community in Maramureș has been highly successful in living with its neighbours in peace and harmony.

\section{BIBLIOGRAPHY}

\section{LITERATURE}

Antal, Hodinka. A munkácsi görög-katholikus püspökség története. Budapest: Kiadja a magyar tudományos akadémia, 1909.

Bizău, Ioan. Viata in Hristos si maladia secularizarii. Cluj Napoca: Patmos Press, 2002.

Boar, Nicolae. Regiunea transfrontalieră româno-ucraineană a Maramureșului. Cluj Napoca: University of Cluj Press, 2005.

Borca, Vasile. Omenirea secularizată pe pantea suicidară. Baia Mare: Editura Universităţii de Nord, 2008.

Bota, Ioan. Rona de Jos - prezentare monografică. Sighetul Marmației: Viața Creștină, 2005.

Carol, Kacso. Repertoriul arheologic al judeţului Maramureş. Baia Mare: Eurotip, 1992.

Chlanta, Ivan. Pisnja nad Karpatem. Uzjhorod: Karpate, 1994.

Columbeanu, Sergiu. Cnezate şi voievo-date româneşti. Bucharest: Albatros, 1973.

Dermer, Ioan-Marin. Maramureşul Românesc: studiu de geografie. Bucharest: Cartea Românească, 1933.

Filipaşcu, Alexandru. Istoria Maramureşului. 2nd ed. Baia Mare: Gutinul, 1997. 
Gaftone, Vasile. Românii și etniile din Maramureș: o istorie a multietnicismului. Baia Mare: Eurotip, 2010.

Hubarev, Vladislav. Istorija Ukrainy. Donețk: Strim Press, 2007.

Ivanciuc, Teofil. Sighetul Marmaţiei: Ghid cultural-turistic. Sighetul Marmației: Echim, 2007.

Magocsi, Pavlo R. Formuvanya nationalinoyi samosvidomosti: Pidkarpatska Rus, 1848-1948. Ujgorod: Grinta, 1994.

Mariș-Dăncuș, Țelman Ion, and Elisabeta Faiciuc. Cuhea în istoria și cultura Maramureșului. Sighetul Marmației: Aska Grafica, 2005.

De Apșa, Ioan Mihaly. Diplome maramureșene din sec. XIV-XV. Istoria Comitatului Maramures. Maramures-Sziget: Mayer și Berger, 1900.

Nagniebeda-Tverdohleb, Tatiana. Migration - the drama of our contemporary times. XXI Century School, and the increasing phenomenon of migration (Chișinău: Edmonton Press, 2013).

Olaşin, Andrei. Istorija Zakarpatia. Mukacevo: Karpatska vezha, 2009.

Pavliuc, Nicolae. Istorija Ukrajiny. Kiev: Orizonturi, 1989.

Pavliuc, Nicolae. "Z istoriji ukrajinskykh sil Maramoreschchyny." Novyi vik (September-October 1957), 134-136.

Pavliuc, Nicolae. "Do istoriji ukrajinskykh sil Maramoreschchyny.” Vilne slovo 16-17 (1990).

Penzeș, Vasile. Історія Украӥнсъкої грекокатолицъкої церкви в Марамурені та всієї Румунії. Lviv: Limes-Lecton, 1994.

Petrovai, Ion. Multiculturalism în Ţara Maramureşului: valori culturale ucrainene. Cluj Napoca: Romanian Academy, Transylvanian Studies Centre, 2007.

Popa, Radu. Ţara Maramureşului în veacul al XIV-lea. Bucharest: Ed. Academiei Republicii Socialiste România, 1970.

Roșca, Nuțu. Istoria Bisericii Ortodoxe Române din Maramureş. Baia Mare: Romanian Orthodox Episcopate of Maramures, Sătmarului, 2015.

Rusu, Raularian. Organizarea spatiului geografic în Banat. Timișoara: Mirton, 2007.

Songota, Bela. The Poienile de sub Munte Commune, Maramureș - Monography. Petrova: Tara Maramureșului, 2015.

Ștefănescu, Ion. Arta veche a Maramuresului. Bucharest: Meridiane, 1968.

Suciu, Coriolan. Dicţionar istoric al localităţilor din Transilvania. Vols. 1-2. Bucharest: Editura Academiei Republicii Socialiste România, 1967-1968.

Statutes of the Romanian Orthodox Church, adopted by the Holy Synod of the Romanian Orthodox Church on November 28, 2007. Romanian edition. Bucharest: Institutul Biblic și de Misiune al Bisericii Ortodoxe Române, 2007.

Țelman, Ion, Ioana Mariș-Dăncuş, and Elisabeta Faiciuc. Cuhea în istoria şi cultura Maramureşului. Sighetul Marmației: Muzeul Maramureşului, 2005.

Țuțea, Petre. Omul - Tratat de antropologie creștină. Vol. 1, Problemele sau Cartea întrebărilor. Iași: Timpul Press, 1992.

Vișovan, Ștefan. Interferenţe româno-ucrainene în toponimia Maramureşului. Baia Mare: Umbria, 2001

Vlachos, Hierotheos. Secularismul. Un cal troian in Biserica. Galați: Egumenița, 2004. 
WEBSITES

"Problemele parohiilor din Vicariatul Ortodox Ucrainean în atenția Permanenței Consiliului Național Bisericesc.” Basilica, September 3, 2009. Accessed January 12, 2021. http:// basilica.ro/ro/stiri.

Address no. 1432 (March 16, 1990) of the Patriarchate of Romania. Accessed January 15, 2021. Available in Romanian at http://patriarhia.ro/cancelaria-sfantului-sinod-197.html.

"Povestea iei românești: cămașa populară, de la origini și până în present.” Invie Traditia. Accessed February 27, 2021. https://www.invietraditia.ro/editorial/ia-romaneasca.

\section{HISTORIA I TRADYCJA PRAWOSŁAWNYCH WSPÓLNOT UKRAIŃSKICH W MARAMURESZU}

$$
\text { Streszczenie }
$$

Rejon Maramureszu, umiejscowiony w północnozachodniej części Rumunii, zawsze był jednym z najstarszych ośrodków religijnych Transylwanii. Pierwsza część artykułu ukazuje najważniejsze wydarzenia w historii prawosławnych wspólnot ukraińskich, żyjących w tym regionie, jak i strukturę oraz rozwój lokalnego Kościoła prawosławnego. Druga część opracowania przedstawia kluczową rolę wiary prawosławnej w tworzeniu relacji przyjaźni i współpracy pomiędzy mniejszością ukraińską i rumuńską większością w tym rejonie. Dzięki wspólnej wierze oraz przekonaniom religijnym wspólnoty ukraińskie mają szansę zachować swe zwyczaje, tradycje i kulturę, jak i podtrzymywać swoje dziedzictwo duchowe.

Słowa kluczowe: Maramuresz; prawosławie; Ukraińcy; tradycja; tożsamość. 